\title{
DE VROEGE JAREN VAN DE VERENIGING
}

Het is mij een bijzondere eer en genoegen u bij gelegenheid van deze feestelijke bijeenkomst van onze Vereniging in de CODA, dit fraaie tijdelijke onderdak van onze collectie in Apeldoorn, te mogen toespreken. De laatste keer dat mij dit voorrecht verleend werd, was bij de viering van de vijfenzeventigste verjaardag van de Vereniging. Ik heb toen van die gelegenheid gebruik gemaakt $u$ het een en ander te vertellen over het zeer gevarieerde en kleurrijke gezelschap van hoogst individualistische verzamelaars dat aan de wieg heeft gestaan van onze Vereniging en dat zijn onuitwisbaar stempel op het wel en wee van de Vereniging en op het karakter van ons Museum van Aziatische Kunst heeft gedrukt. Alhoewel ik die verzamelaars, van Addens tot Zorab, ook dit keer niet over het hoofd wil zien, zou ik toch deze keer in mijn terugblik op de geschiedenis van Vereniging en Museum wat meer aandacht willen vragen voor de met een inspirerende visie en vooruitziende blik begiftigde personen die de Vereniging van een nieuwkomertje in het Nederlandse culturele landschap getransformeerd hebben in de gevestigde, permanente culturele instelling die wij thans vormen. Maar om in de sfeer van deze feestelijke bijeenkomst te blijven, wil ik dat niet al te plechtig doen. Ik wil u daarom het een en ander over onze vroegere bestuurders vertellen wat $u$ beslist niet in de literatuur en waarschijnlijk evenmin in de archiefstukken zult vinden en waarvan ik misschien wel de enig overlevende getuige ben.

\section{Herman Visser}

Allereerst moet ik hier echter, heel in het kort, een persoonlijke noot inlassen omdat dit voor diegenenen onder u die mij niet kennen - en dat zijn er zo langzamerhand heel wat - voor een goed begrip van wat volgt noodzakelijk is. In 1947 trad ik, negentien jaar oud en tweedejaars student in de sinologie aan de Leidse Universiteit, in dienst van de Vereniging als assistent van de conservator Herman Visser voor twee dagen in de week. Die benoeming was het resultaat van wat we nu long range planning noemen. Visser had namelijk in die tijd nog tien jaar voor de boeg voor het bereiken van de pensioengerechtigde leeftijd. Het bestuur van de Vereniging was zich er wel van bewust - en in dit opzicht was het zijn tijd vooruit - dat de beoefening van Aziatische kunstgeschiedenis een vak was dat alleen op basis van een gedegen kennis van taal en cultuur met succes kon worden beoefend. Men had al eerder geprobeerd iemand aan te trekken die zich in een der Oosterse talen had bekwaamd, maar dat was om praktische redenen op niets uitgelopen. Men kon namelijk van iemand die de academische opleiding al

Afbeelding 1 Haan, inkt en kleur op

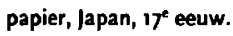
Rijksmuseum, WAK, inv.nr. AK-MAK-954 achter de rug had redelijkerwijs niet verwachten dat hij of zij het geduld en, nog belangrijker, het financiële offer zou kunnen opbrengen om tien jaar op een vaste aanstelling te wachten. En zo kwam men dus logischerwijs op het idee dan maar een beginnend student aam teatrekkén. Brill. comø4/26/2023 09:07:22AM 
Herman Visser was een man die over heel Europa en Noord-Amerika contacten had met vooraanstaande collega's - toen veel kleiner in aantal dan $\mathrm{nu}$ - en bekende verzamelaars, toen veel talrijker dan thans, van Stoclet in Brussel, Mrs. Sedgwick en Sir Percival David in Londen en Baron Eduard von der Heydt in Ascona om er slechts enkele te noemen. Het resultaat van mijn vroegtijdige benoeming was dat ik door Visser in kennis werd gebracht met talrijke persoonlijkheden in de Aziatische kunstwereld van een oudere generatie die voor de meeste van mijn latere collega's van mijn eigen leeftijd of jonger slechts namen of legendarische figuren zijn. Toch was mijn vroege komst in het museum in één opzicht helaas reeds te laat, namelijk om de belangrijkste stichters van onze Vereniging, Mr. G.J. Verburgt en Mr. H.K. Westendorp, persoonlijk te leren kennen. Het beeld dat ik mij van hen beiden heb kunnen vormen gedurende mijn twintig jaar bij het museum berust dan ook voornamelijk op de mondelinge overlevering van hun weduwen, die ik beiden goed heb gekend, op de vele verhalen van meneer Visser, op de stille getuigenis van de door die twee verzamelaars aan ons nagelaten kunstwerken en op diverse bewaard gebleven notities en andere archiefstukken.

Het uiteindelijk blijvende succes van de Vereniging door de vorming van een eigen collectie en de stichting van een permanent museum heeft oneindig veel te danken aan de verziende, idealistische visie van Herman Visser en het onvermoeibaar dynamische doorzettingsvermogen - zijn critici spraken wel eens onvriendelijk van een 'bulldozermentaliteit' - waarmee hij de vele obstakels en vooroordelen die hij op zijn weg vond wist op te ruimen of te omzeilen en zo veel van zijn denkbeelden uiteindelijk wist te verwezenlijken. Zonder twijfel zou er zonder hem nooit een museum zijn gekomen. Toch moeten wij daarom nog niet onderschatten hoezeer de groei en bloei van de Vereniging, en later van ons museum en van onze collectie geprofiteerd hebben van het wijs beleid en de uitzonderlijke bestuurlijke kwaliteiten van onze stichters Verburgt en Westendorp en van vroege voorzitters als Van der Mandele.

\section{Verburgt en de kat van Stheeman}

Laat ik beginnen met iets te vertellen over mijnheer Verburgt. Wat ik ga zeggen heb ik overigens niet van zijn weduwe gehoord - zij heeft het waarschijnlijk opzettelijk voor mij verzwegen - maar het is mij eerst lang na haar overlijden bij toeval duidelijk geworden, toen ik na het vinden in het archief van de Vereniging van mijnheer Verburgt's testament, op iets merkwaardigs werd attent gemaakt. Maar eerst iets anders. In de leeszaal van het Rijksprentenkabinet verscheen in de vijftiger jaren zo af en toe een oude, excentrieke man, zo haveloos gekleed dat hij er uitzag als een clochard. Deze heer, A. Stheeman geheten, was in zijn jonge jaren directeur van Teylers Genootschap in Haarlem geweest. Een begaafd man met een wijde kennis van kunst, had hij het museumberoep vaarwel gezegd en jarenlang een soort van zwerversbestaan geleid, dat hem o.a. naar Tunis had gebracht. Op een goede dag dook hij onverwacht in de leeszaal van het Rijksprentenkabinet op en beweerde dat hij daar een belangrijk notitieboek had laten liggen. De dienstdoende bibliothecaresse, juffrouw Marjorie Bottenheim, die daar sinds tientallen jaren gewerkt had, ging zonder een ogenblik te aarzelen naar een kast en haalde er een notitieboek uit en zei: "Hier is uw notititieboek, $u$ heeft 
De heer Stheeman wist veel van Japanse prenten, maar Karel Boon, die over de Japanse verzameling van houtsneden ging, vond hem maar griezelig. Hij werd al zenuwachtig wanneer hij de man zag komen en probeerde zo gauw mogelijk van hem af te komen door hem aan mij over te doen. Nu moet $\mathrm{u}$ weten dat ik ben opgegroeid als zoon van een directeur van een psychiatrische inrichting, zodat ik van huis uit gewend ben met excentrieke individuen om te gaan. In de gesprekken die ik zo af en toe met de heer Stheeman had, sprak hij altijd heel interessant over zijn collectie van Japanse houtsneden en over de buitenlandse verzamelaars met wie hij, naar zijn zeggen, geregeld in contact stond. Zodra ik echter de namen die hij noemde in de literatuur naging, bleken deze namen evenwel doorgaans die van verzamelaars te zijn die al meer dan veertig jaar geleden gestorven waren. Zo werd mij allengs duidelijk dat het geheugen van de heer Stheeman weliswaar nog perfect functioneerde, maar dat zijn tijdsbesef, zoals Juffrouw Bottenheim al eerder had kunnen constateren, totaal was verdwenen.

Op zekere dag gaf Mevrouw Westendorp, de bekende schilderes Betsy Westendorp-Osieck, een der 'Amsterdamse Joffers' en de weduwe van onze eerste voorzitter, mij enkele kleine notitieboekjes waarin haar man over de jaren al zijn kunstaankopen had genoteerd. Bij een Japanse schildering van een haan, nu in ons museum (afb. 1), stond de notitie "gekocht van A. Stheeman" en, tussen haakjes, "(die van de kat!)". Toen ik Meneer Visser vroeg hoe dat met die kat zat, vertelde hij mij het volgende. De heer Stheeman was de trotse eigenaar van een fraaie, $35 \mathrm{~cm}$. hoge Egyptische bronzen kat uit de Ptolemaeische periode. Als Stheeman om de een of andere reden geld nodig had - hoogstwaarschijnlijk omdat hij een ander kunstwerk op het oog had ging hij ergens, meestal bij een andere verzamelaar geld lenen, voor de terugbetaling waarvan hij dan zijn befaamde kat als onderpand gaf. Hij schijnt dat in de loop der jaren enkele malen gedaan te hebben, om dan steeds bij het verstrijken van de termijn, op het laatste moment de lening af te komen lossen. Op een goed ogenblik klopte hij bij de heer Verburgt aan, die hem maar al te graag het geld leende in de hoop zo de uiteindelijke eigenaar van de befaamde kat te kunnen worden. Toen de datum, waarop de lening moest worden afgelost aanbrak, bleek Verburgt echter niet in den Haag te zijn. Of dit opzet was en of Stheeman echt op tijd met zijn geld kwam of niet, heb ik zoveel jaren later niet kunnen achterhalen. Wat er dan ook werkelijk gebeurd moge zijn, het eind van het liedje was dat Verburgt het stuk behield, en dat hij de kat in zijn testament aan de Vereniging vermaakte. Toen de heer Verburgt echter kwam te overlijden, heeft zijn weduwe, die het kennelijk niet eens was geweest met de wijze waarop haar man de kat had verworven, het dier prompt aan wat zij beschouwde als de rechtmatige eigenaar geretourneerd. Zo kon de kat in 1938 in de tentoonstelling voor het veertigjarig regeringsjubileum van Koningin Wilhelmina als eigendom van de heer Stheeman worden tentoongesteld.

Toen de heer Stheeman een volgende keer over zijn recent bezoek aan de collectie Gillot kwam te spreken, een collectie die aan het begin van de twintigste eeuw in Parijs was geveild, zei ik langs mijn neus weg: "Meneer Stheeman, hoe staat het nu eigenlijk met uw kat?" Opeens kwam er een gloed van echte verzamelaarshartstocht in zijn ogen en hij zei: "De kat verkoop ik nooit!" Aangezien hij inmiddels onderdak had gevonden bij Hulp voor 
zou bevinden. Het antwoord was: "In bruikleen in het Musée du Cinquantenaire in Brussel".

Kort daarna kwam mijn collega Meijle Haga van het Prentenkabinet mij vertellen dat de heer Stheeman gestorven was. Mijn advies aan de familie van Stheeman, aan wie Haga, als mijn geheugen mij niet bedriegt, in de verte geparenteerd was, om eens bij het museum in Brussel te informeren werd aanvankelijk niet au serieux genomen, omdat Stheeman altijd over collecties sprak die hij al vele jaren geleden had verkocht.

Maar ik had die gloed in zijn ogen gezien en toen op mijn aandringen toch contact werd opgenomen, bleek de kat inderdaad in bruikleen bij het museum in Brussel te zijn. Het lijdt geen twijfel of de familie zou zonder deze informatie van mij nooit dat stuk hebben teruggekregen. Daarom stelde ik de erven voor het stuk allereerst tegen taxatiewaarde aan het Museum van Oudheden in Leiden aan te bieden. Zij gingen daarmee akkoord, maar tot mijn verbazing had het Museum geen interesse in het aanbod. De kat werd kort daarna in Londen geveild en brak alle records voor dat soort Egyptische antiquiteiten. Nog jaren later, toen ik eens bij Eskenazi een veel kleinere versie van de kat zag, zei Giuseppe Eskenazi: "niet te vergelijken met de kat van Stheeman", en citeerde meteen de datum van de veiling en het bedrag waarvoor het stuk geveild was. Daarmee wil ik maar zeggen dat de heren Stheeman en Verburgt kennelijk beiden een goed oog voor Egyptische kunst hadden.

\section{Van der Mandele en de vloek van de Boeddhakop van Borobudur}

Na het overlijden op hoogbejaarde leeftijd van mijn vroegere collega in het Rijksmuseum, Theo Lunsingh Scheurleer, met wie ik vele jaren vriendschappelijk in het Rijksmuseum heb samengewerkt, ben ik de enige nog levende persoon die bij de hier volgende hoogst merkwaardige gebeurtenis in het leven van onze voorzitter Van der Mandele betrokken is geweest. Ik doe dat niet alleen omdat dit voorbeeld van wat in de kansberekening seriality wordt genoemd het waard is verteld te worden, maar ook omdat het een interessant licht werpt op een nu bijna totaal vergeten aspect van het verzamelen van Indonesische kunst.

Korte tijd na mijn indiensttreding bij ons museum stuurde Meneer Visser mij naar het bankierskantoor Vermeer \& Co., de bank waar onze voorzitter Van der Mandele de directie voerde. Ik kwam daar om een stenen kop van een boeddha van Borobudur op te halen die de heer en mevrouw Van der Mandele aan onze Vereniging wilden schenken ter gelegenheid van het dertigjarig bestaan van de Vereniging. De viering van de $25^{\mathfrak{c}}$ verjaardag had men vanwege de oorlogsomstandigheden achterwege gelaten. Ik pakte de prachtige, uit donkergrijze andesiet gebeeldhouwde Boeddhakop van Borobudur in het voor dit doel meegebrachte kistje, nam een taxi en transpor-

Afbeelding 2 (rechts) Hoofd van een boeddha, steen, Indonesie, Centraal-java, Borobudur, ca. 800 . Rijksmuseum, WAK, inv.nr. AK-MAK-239 teerde de nieuwe aanwinst onverwijld naar het museum. De heer Van der Mandele, een zeer gedistingeerd uitziende oud cavalerie officier, had mij, een jong broekje, geen tekst en uitleg gegeven, maar het duurde niet lang of meneer Visser vertelde mij in geuren en kleuren de merkwaardige voorgeschiedenis van de schenking. Kort tevoren had de heer Van der Mandele op zijn kantoor onverwacht bezoek gekregenavan eren man, die beweepde 09: 07:22AM 


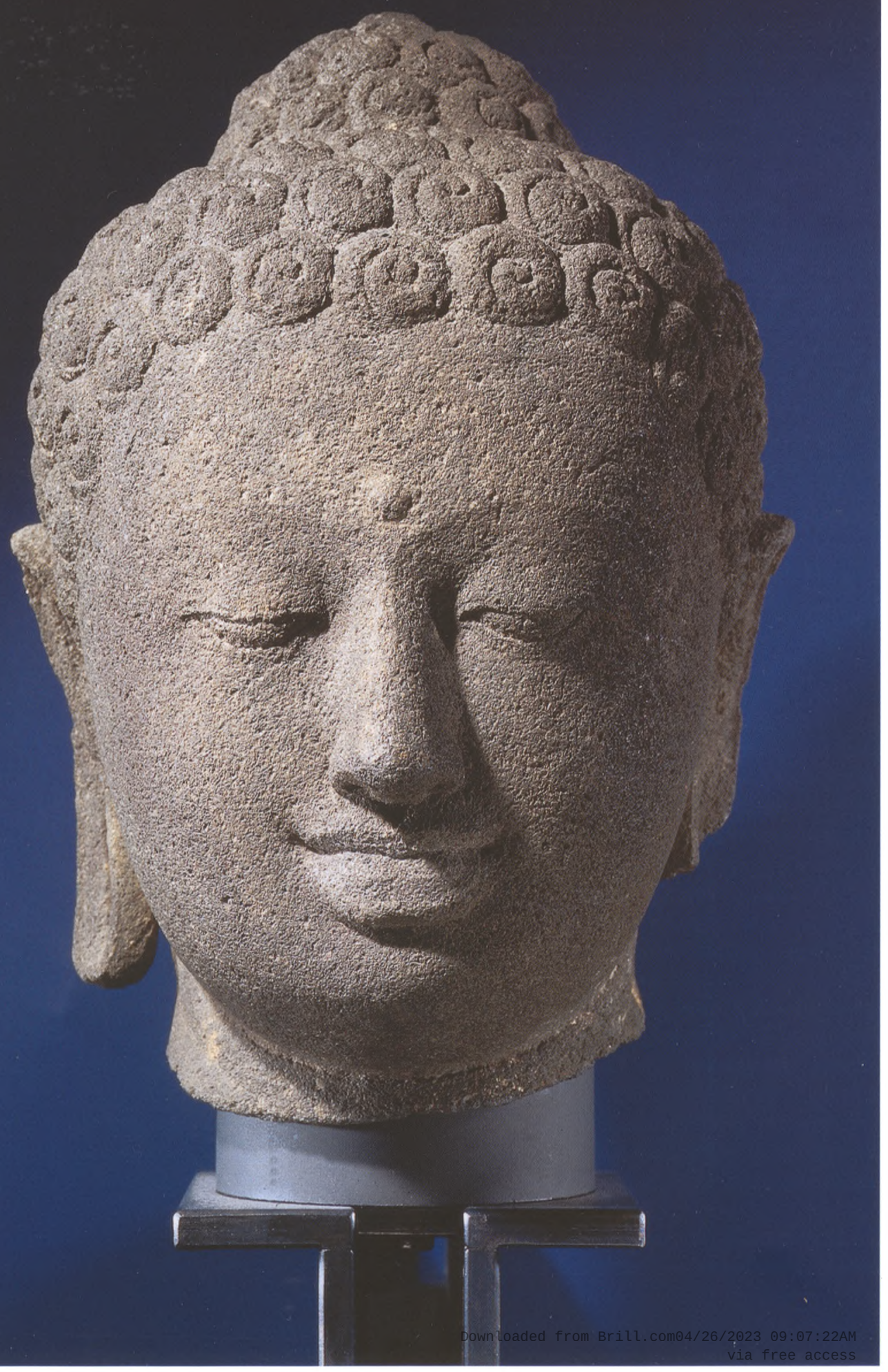


gehoord te hebben van zijn verzamelaarsactiviteiten en hem daarom een Boeddhakop van Borobudur wilde verkopen. Van der Mandele had daar wel oren naar, maar toen hij op de hem eigen diplomatieke wijze naar de prijs informeerde, was hij verbaasd te horen hoe laag de vraagprijs was. Toen de man zijn aarzeling, verrassing of misschien zelfs wel wantouwen bespeurde, verschafte hij van der Mandele de volgende toelichting. Hij had, zo zei hij, de boeddhakop gekocht van een man die failliet gegaan was. Deze had hem verteld dat er op de kop een vloek rustte die iedere eigenaar van het stuk tot de bedelstaf zou brengen. Nu ook voor hem zelf deze voorspelling opnieuw was uitgekomen, zag hij zich genoodzaakt voor een zacht prijsje afstand te doen van het stuk. Van der Mandele zag er geen been in ditzelfde risico te nemen. Maar toen hij die avond thuis kwam en zijn vrouw met de nieuwe aanwinst wilde verrassen, wilde zij onder geen beding het stuk zelfs maar in huis hebben. Het bleef in de achterbak van de auto, kwam de volgende dag terug naar Vermeer \& Co. en direct daarop besloot Van der Mandele het stuk aan de Vereniging te schenken (afb. 2).

Ik was deze geschiedenis, die van 1948 dateerde, allang vergeten, toen ik vele jaren later in het archief van het museum een stapel foto's vond van een mij onbekende verzameling van elegante Franse meubelen, fraaie gobelins en andere antiquiteiten. Tot mijn verbazing stond op een van deze interieurfoto's, temidden van al dat fraais, de Boeddhakop van Borobudur. Ik hoefde maar een paar passen uit mijn kantoor te gaan om de foto met het beeld te kunnen vergelijken. Er was geen enkele twijfel aan: het was dezelfde kop. Ik stapte met de foto in de hand naar het kantoor van Scheurleer, de museumautoriteit op het gebied van kunstnijverheid, en vroeg hem of hij misschien de collectie zou kunnen identificeren. Scheurleer bekeek de foto en zei, na een korte stilte, "Het is de collectie van mijn vader." Op dat moment herinnerde ik mij vroeger eens gehoord te hebben, waarschijnlijk uit de mond van meneer Visser, hoe de vader van Theo Scheurleer, een bankier, failliet was verklaard. Na enig peinzen voegde Scheurleer eraan toe: "Mijn vader vertelde mij dat hij het beeld gekocht had van een man die bij hem thuis aan de deur kwam, en hem waarschuwde met een verhaal dat er een vloek op het stuk rustte, zodat elke eigenaar ervan tot de bedelstaf zou worden gebracht."

Jaren later, toen ik mij voor het eerst verdiepte in de oude Notulen van de Directievergaderingen van het Bataviaasch Genootschap van Kunsten en Wetenschappen, begon ik mij te realiseren dat de vrees voor de stille kracht van oude kunstvoorwerpen van Indonesische herkomst veel ouder is dan die van mevrouw Van der Mandele. In de notulen wordt namelijk meermaals gewag gemaakt van oude, bij graafwerk toevallig ontdekte kunstvoorwerpen, die door de Javaanse bevolking naar het museum werden gebracht omdat de eerlijke vinder geloofde dat het hem allerlei onheil had gebracht. Die vrees was soms zo sterk dat de vinders zelfs de door het Genootschap aangeboden financiële vergoeding van de hand wezen. Daarbij komt dan ook nog de overtuiging dat alleen al door het deponeren van het gevreesde object in het museum, de duistere macht van het stuk werd teniet gedaan. Dit onder de Javanen algemeen verbreide idee wijst erop dat het museum van het Bataviaasch Genootschap, gesticht en beheerd voor en door Nederlanders, door de Indonesische bevolking als een Fremdkörper werd beschouwd dat niet in hun wereld paste en waarop de bovennatuurlijke krachten, waaraan zij zichzelf ondergeschikt achtten, geen enkelel vat haddent. com04/26/2023 09:07:22AM 
Maar, zo zult u zich nu wellicht afvragen, heeft de Boeddhakop van Borobudur, door de genereuze schenking door meneer en mevrouw Van der Mandele van dat stuk aan het museum, daardoor ook zijn bovennatuurlijke kracht verloren of is de vloek van de boeddha nogmaals werkelijkheid geworden? Ik moet onmiddellijk toegeven, dat het aankoopfonds van de Vereniging, kort na de intrede van de boeddhakop in het museum, volledig uitgeput raakte. Maar dat is eerder een onvermijdelijk gevolg van Herman Visser's actieve aankoopbeleid dan van een bovennatuurlijke, duistere vloek van de boeddha.

\section{De bovennatuurlijke kracht van de boeddha's van Borobudur}

Over de bovennatuurlijke kracht van de boeddha's van Borobudur kan ik u nog een andere persoonlijke ervaring melden. Kort na de plechtige heropening van de gerestaureerde Borobudur pleegden onbekende daders, naar alle waarschijnlijkheid moslimfundamentalisten, een aanslag op het monument. Nadat zij als gewone bezoekers toegang tot het monument hadden verkregen, gooiden zij door de ruitvormige en vierkante openingen in de holle stupa's van de ronde terrassen negen tijdbommen naar binnen, die waarschijnlijk kort na hun vertrek explodeerden. Een week later vloog ik naar Indonesië om met eigen ogen de schade te inspecteren. Alhoewel wij allemaal diep geschokt waren door dit zinloze vandalisme, ontdekte ik toch twee of drie lichtpuntjes in dit betreurenswaardige incident. In de eerste plaats hadden de daders geen rekening gehouden met het feit dat de kracht van de explosie grotendeels door de perforaties in de stupa's zou ontsnappen, waardoor de schade beperkt bleef. Een geluk bij een ongeluk was dat het team van ervaren restauratoren, dat zojuist de reconstructie van Borobudur had uitgevoerd, nog niet was ontbonden en direct de restauratie van de getroffen stupa's ter hand kon nemen. Maar het meest merkwaardige van alles was het volgende. Toen men systematisch alle stupa's afging om te zien of er wellicht nog meer bommen waren verborgen, bleek er een springlading te zijn waarvan de ontsteking niet had gewerkt en die als gevolg daarvan niet was geëxplodeerd. Dat was nou net die in de stupa waarin de boeddha is geplaatst, die door de plaatselijke bevolking Bima wordt genoemd en aan wie altijd al allerlei bovennatuurlijke krachten werden toegeschreven. Toen ik, nog maar tien dagen na het incident, Borobudur bezocht, had het nieuws van dit sterke staaltje van Bima's macht zich al als een lopend vuurtje verspreid. Ik zag lange rijen Indonesiërs, allen geduldig wachtend op hun beurt om Bima te mogen aanraken en zo iets van zijn bovennatuurlijke kracht te verwerven. Als de daders inderdaad door islamitische godsdienstijver waren geinspireerd, had hun daad een effect gehad dat zij slechts als een onmiskenbare bevestiging van puur bijgeloof kunnen hebben betreurd.

\section{Jonkheer D.C. Röell, Hoofddirecteur van het Rijksmuseum}

Maar nu echter iets heel anders. Naast de voortreffelijke stichters en voorzitters die ik hier genoemd heb, moet vooral aan een andere persoon aandacht worden geschonken die voor het voortbestaan van Vereniging en Museum in hun huidige nieuwe constructie van doorslaggevende betekenis is geweest: Jonkheer D.C. Röell, de Hoofddirecteur van het Rijksmuseum. Zoals u wel bekend, was het Museum van Aziatische Kunst oorspronkelijk gehuisvest in het Stedelijk Museum. Alhoewel niemand mij date do it meep 09:07:22Am 


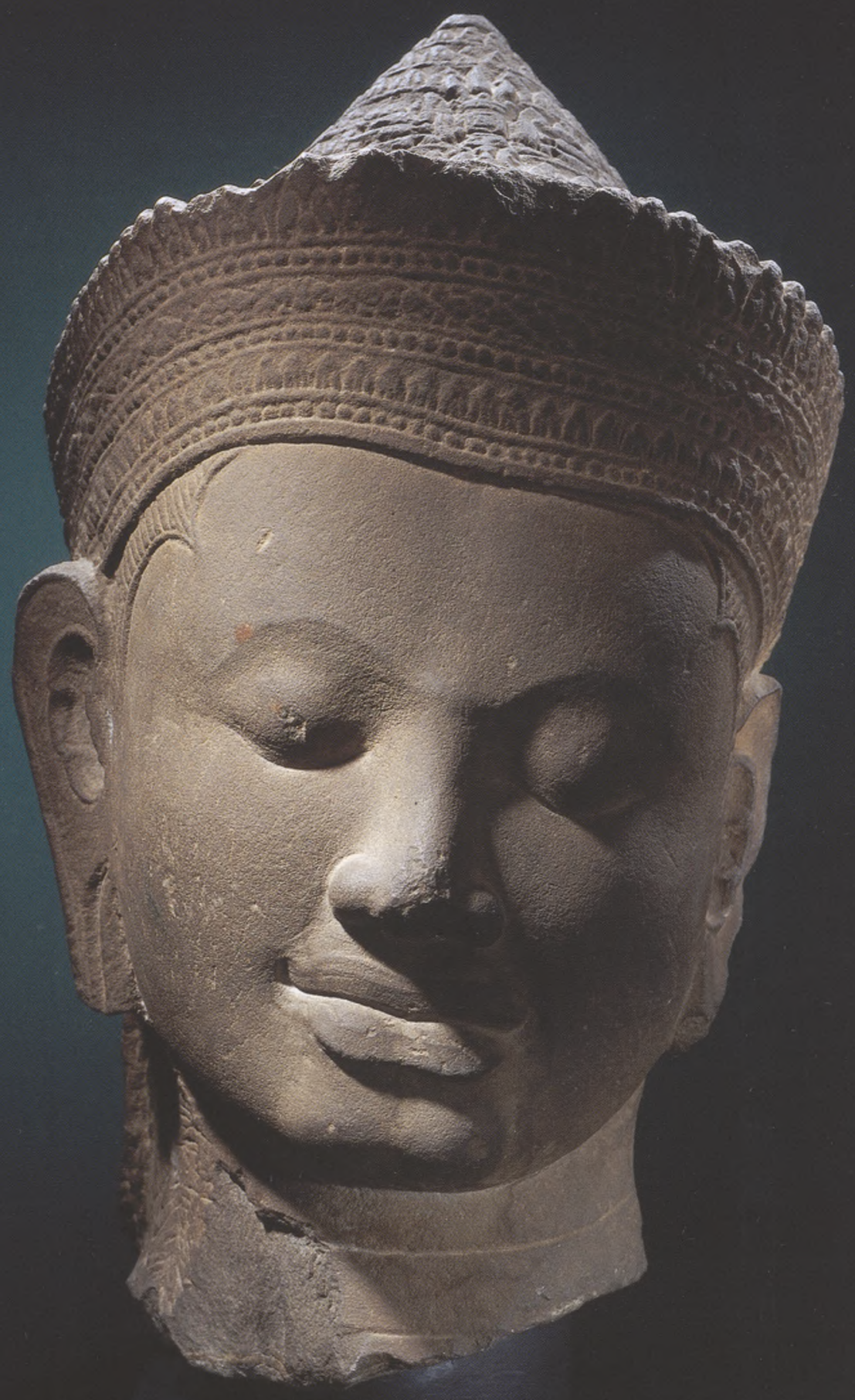

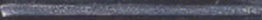


zoveel woorden heeft willen bevestigen, heb ik altijd het vermoeden gehad dat wethouder Van Lier, een oom van Herman Visser, de hand heeft gehad in de overeenkomst van de Vereniging met de Gemeente Amsterdam, waarbij het Museum expositieruimte in het Stedelijk Museum verkreeg en Herman

Afbeelding 3

Hoofd van Vishnu, zandsteen, Cambodja, Angkor-stijl, eerste helft $12^{\mathrm{e}}$ eeuw.

Rijksmuseum, WAK, inv.nr. AK-MAK-224
Toen Röell tot directeur van het Stedelijk Museum werd benoemd, erfde hij aldus Herman Visser als een van zijn conservatoren. Het begin was op zijn zachtst gezegd ietwat onfortuinlijk. Een van de eerste dagen van Röell's directoraat ging de nieuwe directeur 's avonds op inspectietoer door zijn nieuwe museum. Per ongeluk liep hij in het donker - hij wist nog niet waar de lichtschakelaars zaten - in een van de zalen van het Museum van Aziatische Kunst tegen een piëdestal op, waardoor de sculptuur die erop stond - de kop van een Slapende Vishnu uit Cambodja (afb. 3), het meesterwerk dat nu deel uitmaakt van de permanente collectie - op de grond viel. Röell zette het stuk direct weer keurig op zijn plaats terug. Maar toen Visser de volgende dag door de zaal liep, zag hij onmiddellijk dat de Slapende Vishnu anders op zijn voetstuk stond. Bij nadere inspectie bleek hem ook, dat er een buts in de vloer zat en dat bruine was van het parket aan de top van Vishnu's hoofdtooi kleefde. Hoogst verbolgen toog hij naar het bureau van zijn nieuwe directeur, om zich over dit hem niet gemelde incident te beklagen. Met beschaamde kaken moest Röell het door hem veroorzaakte incident opbiechten.

Ondanks dit weinig fortuinlijke begin was de verhouding tussen Visser en Röell er later over het algemeen een van goede samenwerking. Terecht bewonderde Visser de voortreffelijke bestuurlijke kwaliteiten en het natuurlijke gezag, het diplomatieke talent en de gedistingeerde smaak van Röell. De situatie veranderde evenwel toen Röell tot hoofddirecteur van het Rijksmuseum werd benoemd en Jhr. W.J.H.B. Sandberg hem in het Stedelijk Museum opvolgde. Binnen enkele jaren werd het Stedelijk Museum een dynamisch middelpunt van de eigentijdse kunst in West-Europa. Sandberg's beleid, dat in het buitenland alom veel lof oogstte, werd in Nederland vaak fel, en achteraf gezien zeker niet altijd terecht, bekritiseerd. Deze critici werden aangevoerd door de journalist Prange van Het Parool, die - in tegenstelling tot de progressieve sociale opvattingen van die krant, een ietwat oudbakken kunstbeleid voorstond en veel van de eigentijdse kunst als frauduleus belachelijk trachtte te maken. Terwijl de snelle opeenvolging van allerlei toen controversiële tentoonstellingen van moderne kunst veel leven in de brouwerij van de kunstwereld van Amsterdam bracht, werd het Museum van Aziatische Kunst allengs een soort enclave van stilte, een Fremdkörper dat niet langer in zijn omgeving van het Stedelijk Museum paste. Dat Visser zich af en toe openlijk van Sandberg's beleid distantieerde heeft de interne verhoudingen zeker geen goed gedaan. Op een gegeven ogenblik stapte Sandberg naar Röell en stelde hem voor het Museum van Aziatische Kunst naar het Rijksmuseum, naar wat nu de Zuidvleugel genoemd werd, over te brengen. Ik weet niet of Röell en Sandberg er zich toen al van bewust waren een heel oud idee uit de kast gehaald te hebben. Jaren eerder had namelijk de bekende architect K.P.C. de Bazel al eens een schetstekening gemaakt van een aanbouw aan de zogenaamde Breda gevel van het Oudheidkundig Genootschap waarin de Vereniging haar collectie zou kunnen tentoonstellen, met andere woorden, precies de plaats waar het vele jaren later terecht zou komen. Hoe dat ook zij, het voorstel van'Sandberg vieß bij Röellinf goede 09 : $07: 22 \mathrm{Am}$ 
aarde, want het paste voortreffelijk in Röell's eigen strategie om de collectie van het Rijksmuseum een meer internationaal kunstkarakter te geven.

Visser had in zijn jonge jaren, zijn Sturm und Drang-periode, zullen we maar zeggen, het stoutmoedige idee geopperd aan het Museumplein een Rijksmuseum van Buiten-Europese Kunst te openen, waarin onder andere de meesterwerken van de collecties in de Rijksmusea voor Volkenkunde en van Oudheden te Leiden, plus alle andere kunst van buiten Europa die zich in Rijksinstellingen bevond, in een enkel Rijksmuseum voor Buiten-Europese Kunst zouden worden verenigd. Met dit idee, kort na de stichting van de Vereniging in samenwerking met Frits Lugt bekokstoofd en met veel verve door Visser gelanceerd, maakte hij heel wat vijanden. Het plan veroorzaakte grote consternatie en leidde tot het terugtreden uit het bestuur van de Vereniging van alle Leidenaren, inclusief de onvolprezen Professor Jean-Philippe Vogel, die er van tevoren niet eens in gekend was. Nog bijna vijfentwintig jaar later, toen ik als Leids student bij het museum kwam, moest ik tot mijn verbazing constateren dat het Leidse wantrouwen jegens het Museum van Aziatische Kunst, als gevolg van Visser's grootse plannen, nog springlevend en gezond was. Zelfs de komst van een echte Leidenaar in ons museum kon daar blijkbaar maar weinig aan veranderen. Intussen was met de komst van het Museum van Aziatische Kunst in het Rijksmuseum toch nog iets van Visser's oude jeugdideaal, zij het dan minus de schatten van Singosari, werkelijkheid geworden.

Maar nu iets over Röell zelf. Röell was een man van grote visie, die tevens de gave bezat op gewiekste wijze zijn grootse plannen door de doolhof van het vaak wat benepen ambtenarenapparaat in den Haag te kunnen loodsen. Een van zijn grote verdiensten is dat hij de Collectie Mannheimer voor Nederland wist te redden. De collectie van de van oorsprong Duitse bankier Mannheimer, die tegenover het Rijksmuseum aan het Museumplein woonde, was na de dood van de eigenaar zelf tijdens de oorlog door de Duitsers naar Duitsland meegenomen. Na de oorlog werd zij, zoals dat toen heette, gerecupereerd. Later bleek evenwel dat Mannheimer ten tijde van zijn overlijden in feite in staat van faillissement had verkeerd, zodat uiteindelijk de Staat der Nederlanden, waaraan hij een grote som achterstallige belasting schuldig was, in het bezit van de collectie kwam. De verzameling bestond voornamelijk uit Meissen porselein van de hoogste kwaliteit. In die jaren kort na de Tweede Wereldoorlog, toen de schatkist leeg was, werd er grote druk uitgeoefend - met name door het machtige Ministerie van Financiën - om de collectie in het buitenland voor fel begeerde deviezen te veilen. Maar Röell had andere plannen. Vermoedelijk met hulp van de Minister van Onderwijs, Kunsten en Wetenschappen, Cals, waarmee hij in het verzet had samengewerkt, wist Röell een overeenkomst te bereiken, waarbij het overgrote deel van de verzameling Meissen aan het Rijksmuseum kwam en de peperdure, maar artistiek oninteressante serviezen in goud voor veel geld werden geveild. Met het porselein, de meubels en andere voorwerpen van Mannheimer werd het karakter van de afdeling Kunstnijverheid in een slag internationaal (afb. 4).

De verzameling van het Museum van Aziatische Kunst paste dus perfect in Röell's strategie. De ontbindingsclausule van de oorspronkelijke overeenkomst met de Gemeente voorzag in de overdracht van de collectie aan de stad Amsterdam in het geval dat de Vereniging zour ophouden "te bestaan. 09: 07:22AM 


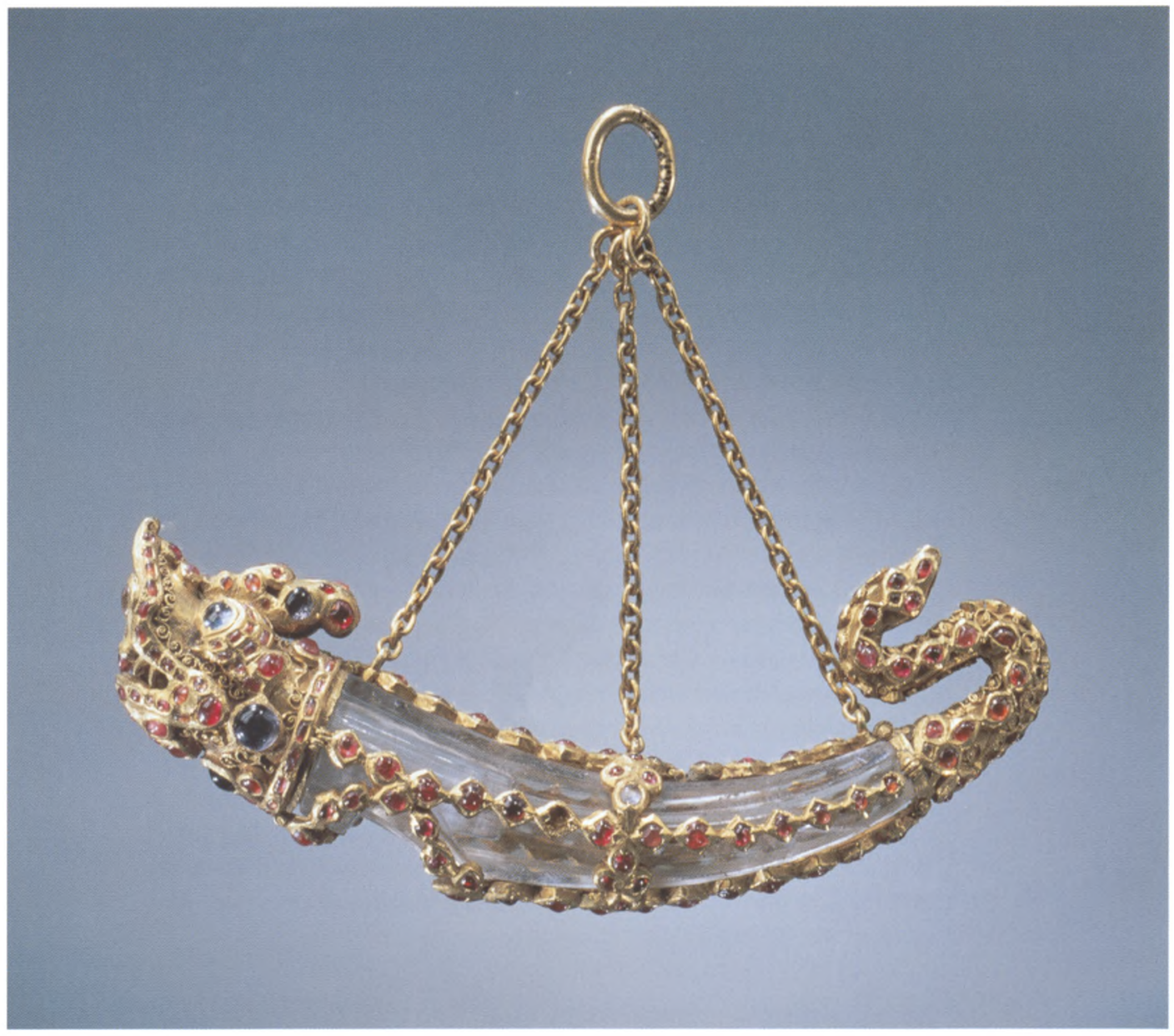

Afbeelding 4

Hanger in de vorm van een dolfijn, bergkristal, goud en robijn, India, 16e eeuw. Rijksmuseum, inv.nr. AK-RBK-17524
Deze clausule stond aanvankelijk een nieuwe overeenkomst met het Rijk in de weg. Zo zijn Herman Visser tot zijn pensioen en ikzelf voor de volgende acht of negen jaar ambtenaren van de Gemeente gebleven, totdat uiteindelijk een formule werd gevonden die het algemeen belang, dat wil zeggen het behoud van de collectie, voorrang gaf. Misschien wel de moeilijkste dag in mijn Amsterdamse carrière was de dag waarop ik de nieuwe hoofddirecteur Van Schendel ging melden dat ik een aanbod uit Boston in overweging had genomen. Toen ik bij hem binnenkwam werd ik gefeliciteerd. Het bleek namelijk de dag te zijn waarop, na jaren van uitstel en trainering, mijn benoeming bij het Rijk was afgekomen.

Maar nu over Röell als persoon, als directeur. Het feit dat drie van zijn jonge conservatoren, Bob Haak, de latere directeur van het Amsterdams Historisch Museum, Emile Meijer, de eerste directeur van het Rijksmuseum Vincent van Gogh en ikzelf als directeur van het Museum of Fine Arts in Boston, alle drie in renovatie en nieuwbouw van musea een levenstalk hebbengevororalen, 09: 07:22AM 
zegt wel iets wezenlijks over Röell's invloed op de hem volgende generatie van museumdirecteuren. Röell was altijd aan het plannen maken voor renovaties in het Rijksmuseum. Er was maar weinig wat hem daarvan kon weerhouden. Toen voor de zoveelste maal door de overheid een bouwstop werd afgekondigd, ging Röell rustig door met de renovatie. Totdat een kamerlid, die op zijn fiets door de onderdoorgang van het museum reed - kan het Nederlandser? - metselaars bakstenen zag wegdragen. Er volgden vragen in de kamer en Röell werd op de vingers getikt.

Röell had een zeldzaam inzicht in architectuur; hij kende Cuypers door en door. Ik herinner mij hoe we eens in de Eregalerij stonden en Röell poneerde dat er iets mankeerde aan de proporties van die zaal. Het bleek kort daarna dat een vroegere directeur, ik geloof dat het Schmidt Degener was, de vloer had laten ophogen. Maar bij al zijn inzicht in het werk van Cuypers stond voor Röell toch zijn doel het museum beter bruikbaar te maken voor onze tijd altijd voorop. Toen een staflid hem op een van onze ochtendbesprekingen, het zgn. ontbijtje, gebrek aan eerbied voor Cuypers verweet, zei Röell: "Ik zie de taak van de hoofddirecteur van het Rijksmuseum niet als één om een krans te leggen op het graf van Cuypers" - en daarmee was de zaak afgedaan.

Röell was een inspirerende figuur. Een van de dingen die hij deed om zijn staf enthousiast te maken en te houden was ons een inzicht te geven in de ambtelijke politiek van zijn directoraat. Zo hield hij ons op de hoogte van de onderhandelingen over de Mannheimer collectie, waardoor wij meeleefden met alle ups en downs en het gevoel kregen dat wij in alles gekend werden. Achteraf gezien was dat natuurlijk niet zo, want Röell was diplomatiek gewiekst genoeg heus niet alles aan ons kwijt te willen. Maar het gevoel alleen al dat wij wisten wat er aan de hand was, maakte dat wij voor hem door het vuur gingen. En alle drie latere directeuren hebben een open beleid gevoerd waarbij de staf zoveel mogelijk in de achtergronden van wat er gedaan moest worden, werden ingewijd.

\section{Het lot van enkele vroege verzamelaars}

Tot aan de integratie van het Museum van Aziatische Kunst in het Rijksmuseum was en bleef de Vereniging voor de uitbreiding van haar collectie uitsluitend aangewezen op de steun van particulieren. De exodus van joodse verzamelaars uit nazi-Duitsland was aanvankelijk ons land ten goede gekomen en had de gelederen van de verzamelaars van Aziatische kunst versterkt. Maar de tweede wereldoorlog heeft het aantal verzamelaars van Aziatische kunst in Nederland sterk gereduceerd. Dat verlies was echter meer het resultaat van emigratie, want nazi-slachtoffers - ik denk bijvoorbeeld aan Mr. Hülsmann, die het slachtoffer werd van een SS-veemmoord - waren er onder die verzamelaars maar weinig, even weinig als er 'foute' verzamelaars waren (één of twee). Het is misschien wel interessant hier aan enkele van die verzamelaars die Nederland door emigratie verloor eens wat meer aandacht te besteden.

\section{- Alfred Schoenlicht en Baron Eduard von der Heydt}

Visser's Asiatic Art in Private Collections in Holland and Belgiurn gaf in zoverre een sterk geflatteerd beeld van het Nederlandse verzamelaarswezen

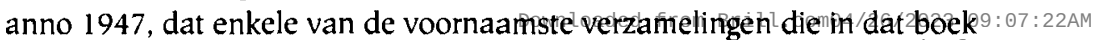


zijn opgenomen allang niet meer in Nederland waren. Daarvan was die van Alfred Schoenlicht veruit de belangrijkste. Alfred Schoenlicht, van Duitsjoodse origine, kwam voor het eerst in aanraking met Chinese kunst toen hij als vertegenwoordiger van de Firma Blohm und Voss stoomlocomotieven aan de Chinese spoorwegen verkocht. Het Chinese spoorwegnet werd aangelegd en het rollend materieel aangekocht met buitenlands kapitaal, waarvoor de door buitenlanders geleide Chinese Maritime Customs garant stonden. Toen in het begin van de $20^{c}$ eeuw de grote steden van Noord-China voor het eerst door een spoorwegnet met elkaar werden verbonden, stuitte men vooral in de nabijheid van oude hoofdsteden als Luoyang en Xi'an bij de aanleg van het tracé op veel grafvelden die een grote hoeveelheid aan antiquiteiten opleverden, vooral uit de Han- en Tang-tijd, toen de Centrale Vlakte het centrum van het Rijk was. De op de aanleg toezicht houdende ingenieurs waren zodoende de eerste buitenlanders die op grafceramiek en graffiguren attent werden gemaakt. Chinese verzamelaars hadden altijd al geweten dat er duizenden van die grafgaven in de Goede Aarde rustten - de Chinese folklore wemelt van spookverhalen waarin graffiguren tot leven komen - maar behoudens enkele uitzonderingen, zoals de Onderkoning Duan Fang, die in 1911 bij de Chinese revolutie werd vermoord, respecteerden Chinezen het diep gewortelde taboe dat op grafroof rustte. Duan Fang verzamelde voornamelijk grafstenen, niet vanwege de historische gegevens die ze bevatten, maar omdat hij de calligrafie van de inscripties apprecieerde. De beroemde schrijver Lu Xun was overigens een van de eerste Chinese verzamelaars van grafceramiek, een liefhebberij die waarschijnlijk uit de tijd van zijn verblijf in Japan stamt. Want Europese en Japanse verzamelaars kenden die schroom niet.

De Zweedse spoorweg ingenieur Orvar Karlbeck, een oude vriend van Duan Fang, werd een bekend verzamelaar van en later kunsthandelaar in oude Chinese bronskunst. Een aanzienlijk gedeelte van het rijke bezit aan vroege Chinese kunst in Zweden is via Karlbeck in dat land terecht gekomen. De laatste vertegenwoordiger van de verzamelaars die via de spoorwegen tot kunst verzamelen waren gekomen, was de Duitse verzamelaar van Chinese bronzen Jurgen von Lochow, wiens collectie zich voor een belangrijk gedeelte in het Museum für Ostasiatische Kunst in Keulen bevindt.

Schoenlicht trad zodoende in de manier waarop hij tot de Chinese kunst kwam in de voetsporen van een oudere generatie van spoorwegmensen. Maar in een tijd dat vrijwel alle Europese en Amerikaanse verzamelaars van Chinese ceramiek nog helemaal in de ban van het Qing-porselein waren ging Schoenlicht's belangstelling al meteen uit naar Song-ceramiek. Hij deelde die belangstelling met onder andere George Eumorfopoulos in Londen en Charles Bain Hoyt in Cambridge, Massachusetts. In de Chinese tentoonstelling van 1929 in Berlijn trad Schoenlicht voor het eerst met zijn collectie in de openbaarheid, maar niet lang daarna besloot hij naar Nederland te verhuizen. Al vroeg heeft hij daar samen met twee van zijn firmanten van de bank die hij daar stichtte (Visser beweerde overigens dat dit buiten hun medeweten was gedaan) een van de grootste bijdragen tot het aankoopfonds van de Vereniging geleverd.

Ondanks zijn langdurig verblijf in Nederland, voor zowel als na de oorlog,

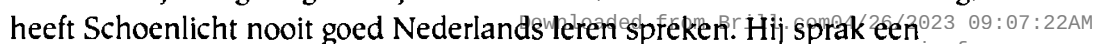


merkwaardig mengsel van Nederlands en Duits. Toen iemand hem een stuk te koop aanbood en hij vond dat het niet in zijn collectie paste, hoorde ik hem zeggen: "Dat schpringt oit het raam van main verzameling", (Das sprengt den Rahmen meiner Sammlung). Maar wat hij miste aan linguïstieke gaven werd ruimschoots gecompenseerd door zijn oog, zijn zeldzaam fijn gevoel voor kunst - en niet alleen voor Chinese kunst. Toen Vermeer's Emmausgangers voor het eerst in de Amsterdamse kunsthandel werd tentoongesteld doorbrak Schoenlicht de eerbiedige, bijna religieuze stilte in de tentoonstelling door hardop te verkondigen dat het schilderij wat hem betreft wel door van Meegeren kon zijn geschilderd. Dat hij als Duits-joodse buitenlander het enthousiasme waarmee ons domineesland de ontdekking van een 'religieuze' Vermeer begroette niet helemaal kon aanvoelen is begrijpelijk, maar dat hij van Meegeren's naam in een adem met de Emmausgangers noemde getuigt wel van een zeldzaam inzicht en bijzondere intuittie. Maar niemand in Nederland heeft naar hem geluisterd.

Alfred Schoenlicht is een van de weinige joodse verzamelaars die erin geslaagd is zich uit de greep van de Duitsers los te kopen. Zijn verzameling had hij overigens met vooruitziende blik al voor de oorlog in bruikleen bij het Museum of Fine Arts in Boston gegeven. Nu was dat loskopen of omkopen van de Duitse autoriteiten een hachelijke onderneming. De slachtoffers hadden geen enkele zekerheid dat de Duitsers, na ontvangst van het losgeld, hun woord zouden houden. De Duitsers, op hun beurt, hadden van hun kant natuurlijk geen enkele garantie dat als zij de slachtoffers eenmaal losgelaten hadden, ze ooit hun losgeld nog zouden krijgen. De enige oplossing van dit dilemma was om het geld te deponeren bij een door beide partijen vertrouwde tussenpersoon in een neutraal land, die het geld pas aan de Duitsers overmaakte als de losgekochte slachtoffers daadwerkelijk Lissabon of een andere neutrale plaats hadden bereikt.

De reden waarom ik hier dit soort duistere mensenhandel ter sprake breng, is dat recent archiefonderzoek in Zwitserland heeft uitgewezen dat een van die tussenpersonen een andere voormalige inwoner van Nederland en eveneens een verzamelaar van Aziatische kunst was: Baron Eduard von der Heydt, de stichter van het Rietberg Museum in Zürich. In de jaren tussen de twee wereldoorlogen woonde Von der Heydt in Nederland. In zijn huis in Zandvoort was de in Doorn in ballingschap levende ex-Kaiser Wilhelm II vaak te gast. Belangrijke stukken uit zijn verzameling waren jarenlang in bruikleen in ons museum, maar ook vele andere musea, van Buffalo, New York tot Berlijn, hadden bruiklenen uit zijn verzameling. Schoenlicht en Von der Heydt waren beiden van Duitse origine, beiden van beroep bankier, beiden verzamelaars van Aziatische kunst, beiden in Nederland woonachtig. Zij moeten elkaar wel hebben gekend. Veel pleit dan ook voor het vermoeden dat bij Schoenlicht's loskoping Von der Heydt een bemiddelende rol heeft gespeeld. Onder welke omstandigheden en precies wanneer Von der Heydt het Zwitserse staatsburgerschap verkreeg is niet duidelijk, maar de recentelijk openbaar gemaakte archiefstukken maken waarschijnlijk dat de schenking van zijn collectie aan de stad Zürich daarbij een rol heeft gespeeld. Hoe dat ook zij, de Amerikanen hebben vele jaren geweigerd de in Buffalo gedeponeerde stukken van de verzameling Von der Heydt - waaronder twee sculpturen uit de grottempels van Tianlongshan, afkomstig uit dezelfde grot als het beeld in onze verzameling, aan de eigenatar te fretourneren. Zifmetássiffeeerden 


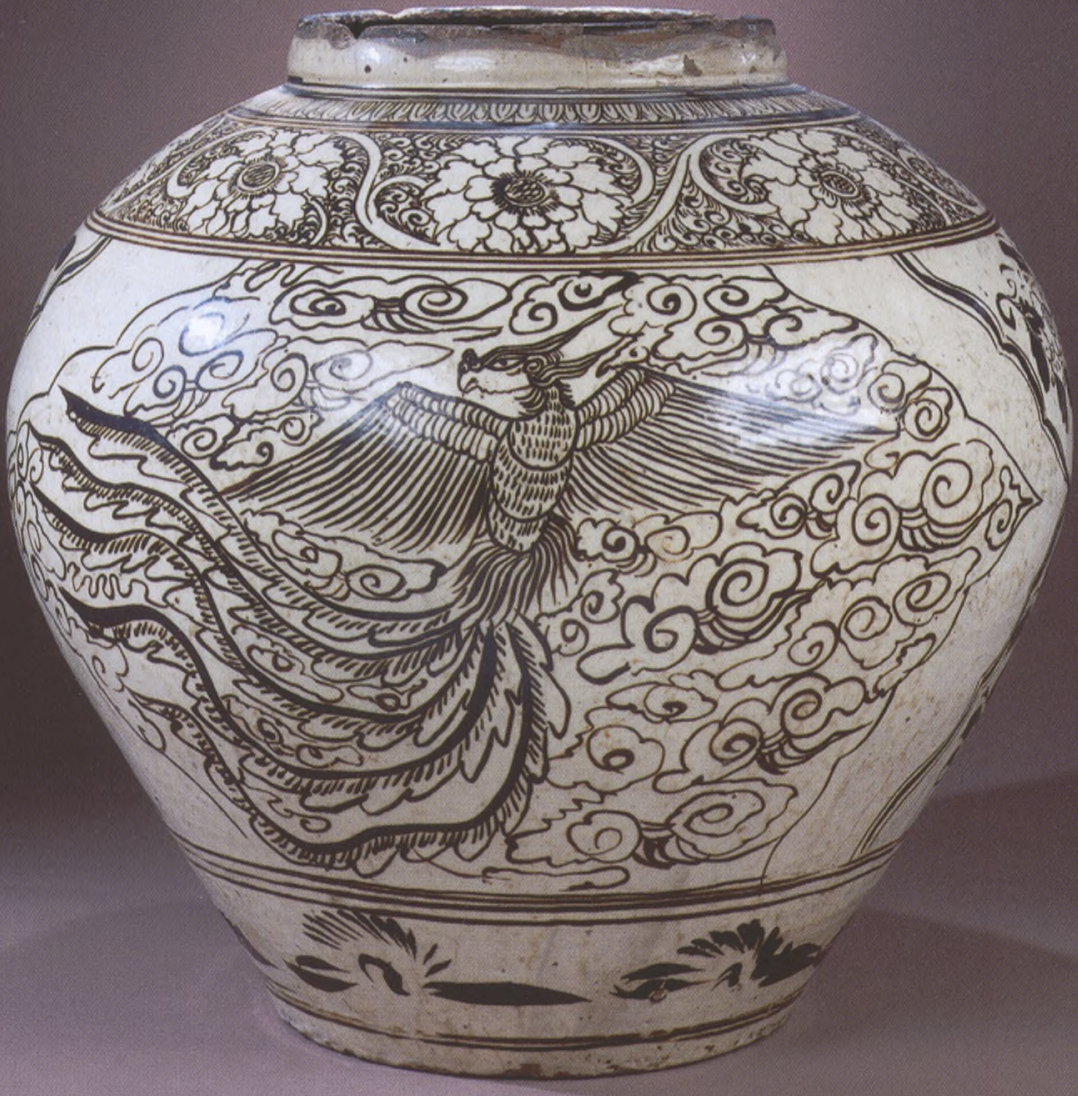

Afbeelding 5

Pot met feniks en draak, steengoed, China, Ming. periode (1368-1644). 
de stukken als alien enemy property. Waarschijnlijk was dit een gevolg van het feit dat Von der Heydt's eerder genoemde geheime transacties niet via een van de gevestigde openlijke Duitse instanties, maar via de schimmige Duitse contraspionagedienst, de zogenaamde Abwehr, liepen. Deze instantie werd door het hoofd van de Amerikaanse inlichtingendienst, Allan Dulles, een broer van de latere secretary of state John Foster Dulles, in Zwitserland nauw in de gaten gehouden, en zo kwam de naam van Von der Heydt in Amerika op een lijst van staatsburgers van een vijand van de Verenigde Staten te staan.

Het is gelukkig allemaal goed afgelopen. Op de boot van Lissabon naar New York ontmoette Schoenlicht een andere vluchteling, een chemisch ingenieur die een idee had pure cafeïne te winnen uit roet in de schoorstenen van Braziliaanse koffiebranderijen. De Amerikaanse warenwet had het gebruik van cafeïne in frisdranken voor de duur van de oorlog verboden. Schoenlicht patenteerde de uitvinding en deed de marketing van het raffinageproces. Hij was het die de verkoop van hun product aan Coca Cola organiseerde, dat voor het gebruik van een afvalproduct een uitzondering op de wet wist te verkrijgen. Het heeft Schoenlicht financieel weer op de been gebracht. Zijn collectie is in 1955, kort na zijn dood, in Londen geveild, en raakte over de hele wereld verspreid van New York tot Australië. Het Rijksmuseum heeft een van zijn stukken, een fraaie Ming-kom met onderglazuur blauwe en email versiering ( $a f b .5$ ). Het was de allereerste veiling waarin Chinese ceramiek van de Tang-en Song-perioden topprijzen bereikte. Er zouden nog velen volgen. Maar het door Schoenlicht geleide bankiershuis Teixeira de Mattos ging jaren na zijn dood roemloos ten onder.

De verzameling Von der Heydt werd ondergebracht in de prachtig gelegen villa Wesendonck, omgedoopt tot Rietberg Museum, in Zürich, waar de over heel Europa en Amerika verspreide collecties bij stukjes en beetjes werden samengebracht. De in de Oostelijke bezettingszone van Duitsland in Sovjethanden geraakte stukken uit de verzameling Von der Heydt werden door de eerste directeur van het Rietberg Museum, de graficus en kunstenaar Johannes Itten, geruild voor wat schrijfgerij dat Lenin bij zijn vertrek uit Zürich in 1917 daar had achtergelaten. Het interessante van die transactie is het feit dat de Russen, wanneer dat in hun kraam te pas kwam, prompt de gevraagde objecten konden vinden. Merkwaardigerwijs heeft niemand daaruit toen de logische conclusie getrokken dat zij de door de museumwereld verloren gewaande kunstcollecties ook in hun bezit hadden. Dat kwam eerst dertig jaar later uit.

\section{- S.H. Minkenhof}

De derde en laatste persoon die ik zou willen noemen van de uit Nederland geëmigreerde verzamelaars van Aziatische kunst is S.H. Minkenhof. Hij was een oom van de vermaarde arts voor infectieziekten Hans Minkenhof, wiens echtgenote, Floor Minkenhof-van Aalten van 1947 tot aan haar dood vijfentwintig jaar later met grote toewijding voor ons museum heeft gewerkt als assistente. De interesse in kunst van de oom, de zakenman Minkenhof, ging oorspronkelijk uit naar Nederlandse kunstenaars zoals Thorn Prikker. Na zijn vertrek uit Nederland woonde hij in New York en het is daar, aan het Institute of Fine Arts van New York University, dat hij de uit Duitsland

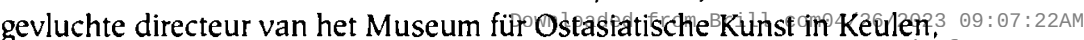




\section{Afbeelding 6}

Graffiguur van een

ambtenaar, aardewerk

met beschildering,

China, Tang-periode

(618-906).

Rijksmuseum, VVAK,

inv.nr. AK-MAK-81

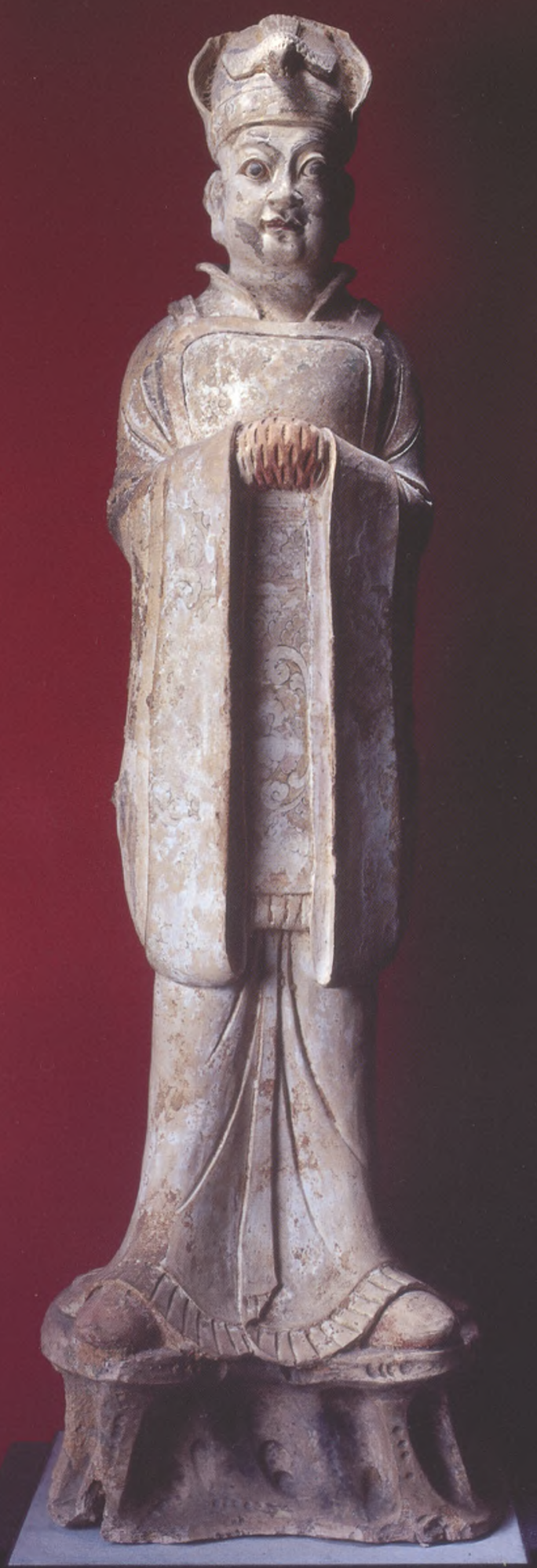


professor Alfred Salmony leerde kennen, die hem later bij zijn verzamelaarsactiviteiten vaak behulpzaam is geweest. Na de Tweede Wereldoorlog verdeelde Minkenhof zijn tijd tussen New York en Parijs, waar hij een fraai appartement bezat. Zijn collectie van Chinese jades verried duidelijk de invloed van professor Salmony, die zich zeer voor jades interesseerde. Ook Herman Visser stond hem vaak met adviezen bij en maakte hem op stukken in de kunsthandel attent in de hoop dat de verzameling uiteindelijk in ons museum zou belanden. Hij was echter altijd een beetje bang Minkenhof negatief advies te geven of hem tegen te spreken omdat hij zijn kans om de collectie te krijgen niet wilde verspelen.

Hoe solide de toezegging was die Minkenhof aan Visser deed of in hoeverre de wens de vader van de gedachte was, weet ik niet. Wel hoorde ik bij toeval van een bevriende museumcollega dat Minkenhof aan enkele andere musea een soortgelijke toezegging had gedaan.

U zult wel begrijpen dat elke keer dat een van ons naar Parijs reisde, een bezoek aan huize Minkenhof de rigueur was. Toen ik dat een keer om dringende reden naliet, kreeg ik daarover een stevige uitbrander. Nu was Minkenhof echter niet helemaal baas in eigen huis. Daar werd namelijk de scepter gezwaaid door zijn huishoudster-kokkin Antoinette. Antoinette was een vrouw met puilogen, zodat Minkenhof's Nederlandse vrienden de Tanggraffiguur van een Chinese mandarijn (afb. 6), die mevrouw Westendorp aan ons museum heeft geschonken, en die dezelfde oogopslag vertoont, Antoinette noemden. Antoinette was een gerenommeerde kokkin, maar zij had een eigenaardigheid. Als zij, om de een of andere reden, een van Minkenhof s gasten niet kon uitstaan, kookte ze met opzet een slecht diner en, om er nog een schepje bovenop te doen, goot zij slechte wijn om in lege flessen van een of ander beroemd chateau. Minkenhof, die heel goed wist wat er aan de hand was, stond daar natuurlijk machteloos tegenover. Nu wilde echter het toeval dat Visser een van de mensen was die in haar verdomhoekje stond. Visser zei wel eens tegen mij: "Weet je, Fontein, dat moet je natuurlijk niet aan Minkenhof zeggen, maar strikt onder ons gezegd, als je mij vraagt, is de grote culinaire reputatie van Antoinette ietwat overdreven, ik zie het gewoon niet zitten". Nu moet ik hieraan toevoegen dat ik zelf blijkbaar niet op Antoinette's boycotlijstje stond en dat ik het verschil, toen ik voor het eerst zonder Visser huize Minkenhof bezocht, duidelijk heb gemerkt.

Minkenhof overleed in het begin van 1956, enkele weken nadat ik Visser op de conservatorpost had afgelost. Voor Visser, die mijn scepsis altijd voor jeugdig pessimisme had gehouden, kwam het verlies van de Minkenhof' collectie als een zware slag. Ook deze collectie raakte over de hele wereld verspreid. Nog onlangs zag ik bij Eskenazi in Londen de fraaie houtsculptuur van Guanyin uit de Minkenhof collectie. Het wekte de herinneringen op die ik hier nu met u deel. 